\title{
ANALISIS PENGARUH KOMUNIKASI DAN INTERAKSI PADA KEGIATAN OUTBOUND TRAINING TERHADAP KERJASAMA PEGAWAI
}

\author{
M. Solkhan \\ Program Pascasarjana Sekolah Tinggi Ilmu Ekonomi Malangkucecwara-Malang \\ Jl. Raya Blimbing Malang \\ m.solkhan@gmail.com
}

\begin{abstract}
This study aims to examine whether communication and interaction in outbound training activities affect employee working behavior. The population of this study were employees, practitioners and teachers from several companies and educational institutions in the Malang region, Pasuruan, Mojokerto, Sidoarjo and Surabaya totaling 376 people, who held outbound training activities with the Training Institute and Human Resource Developers (LPP-SDM ) Nabhan Star with a total sample of 79 people. Using classical assumption test analysis, the coefficient of determination and simultaneous and partial testing are then tested by hypothesis.

The results of the study explained: 1). Outbound training activities through communication and interaction simultaneously have an effect on employee collaboration behavior. This is evidenced by the results of F-Count of 16,360 with a significance value of 0,000.2). Outbound training activities through communication have a partial effect on employee collaboration behavior. This is evidenced by the results of t-count of 16,831 with a significance value of 0,000, while the outbound training activities through interaction do not partially affect the employee's cooperative behavior. This is evidenced by the results of $t$-count of 0.425 with a significance value of 0.672 .

Keywords: Communication, Interaction, Outbound Training, Employee Collaboration.
\end{abstract}

\begin{abstract}
Abstrak
Penelitian ini bertujuan untuk menguji apakah komunikasi dan interaksi pada kegiatan outbound training berpengaruh terhadap perilaku kerjasama pegawai. Populasi dari penelitian ini adalah pegawai, praktisi dan guru dari beberapa perusahaan dan lembaga pendidikan yang ada di wilayah Malang, Pasuruan, Mojokerto, Sidoarjo dan Surabaya berjumlah 376 orang, yang mengadakan kegiatan Outbound Training dengan Lembaga Pelatihan dan Pengembangan-Sumber Daya Manusia (LPP-SDM) Nabhan Star dengan jumlah sampel sebanyak 79 orang. Menggunakan analisis uji asumsi klasik, koefisien determinasi dan pengujian simultan serta parsial kemudian dilakukan uji hipotesis. Hasil penelitian menjelaskan: 1). kegiatan outbound training melalui komunikasi dan interaksi berpengaruh secara simultan terhadap perilaku kerjasama pegawai. Hal ini dibuktikan oleh hasil F-Hitung sebesar 16.360 dengan nilai signifikansi 0.000. 2). kegiatan outbound training melalui komunikasi berpengaruh secara parsial terhadap perilaku kerjasama pegawai. Hal ini
\end{abstract}




\section{JURNAL NOMOSLECA}

Volume 5 Nomor 2, Oktober 2019

dibuktikan oleh hasil t-Hitung sebesar 3.831 dengan nilai signifikansi 0.000 , sedangkan kegiatan outbound training melalui interaksi tidak berpengaruh secara parsial terhadap perilaku kerjasama pegawai. Hal ini dibuktikan oleh hasil t-Hitung sebesar 0.425 dengan nilai signifikansi 0.672 .

Kata Kunci: Komunikasi, Interaksi, Outbound Training, Kerjasama Pegawai.

\section{PENDAHULUAN}

Suatu organisasi atau institusi yang merupakan kumpulan dari pegawai atau karyawan diperlukan saling bekerja sama untuk dapat mencapai suatu tujuan dari lembaga atau organisasi masing-masing. Dalam bekerjasama melaksanakan tugasnya, masing-masing pegawai tentu tidak bisa lepas dengan komunikasi dan interaksi dengan orang lain, entah itu secara langsung atau tidak langsung.

Disisi lain manusia mempunyai banyak perbedaan karakteristik sifat, latar belakang pendidikan, status sosial. Perbedaan yang nyata dalam suatu lembaga antara lain perbedaan tugas dan fungsi tanggung jawab dan kedudukan dalam organisasi tersebut. Berbagai macam perbedaan bisa juga menjadi suatu perekat untuk membangun suatu kekuatan dalam mencapai suatu tujuan, tetapi juga tidak jarang perbedaan yang ada bila tidak di kelola dengan baik akan menjadi bahan pemicu terjadinya salah tafsir, salah persepsi yang bisa menimbulkan benihbenih perpecahan dan ketidak harmonisan dalam suatu organisasi.

Banyak diantara pegawai dengan pengetahuanya dengan kesadaran dan kearifanya dapat menyelesaikan sendiri kekakuan hubungan dan ketidak harmonisan hubungan diantara pegawai itu sendiri. Dan lebih banyak lagi diantara mereka karena keterbatasan pengetahuaan dan kesadaran dan karena mengedepankan egonya masing-masing sehingga tidak bisa menyelesaikan konflik bahkan sebaliknya menambah dan memperbesar konflik. Dalam batas-batas tertentu konflik internal diantara pegawai dalam suatu organisasi masih bisa ditolelir sepanjang tidak mengganggu kinerja produktifitas dan eksistensi dari perusahaan tersebut.

Bagi pimpinan yang peka terhadap suasana tentu harus mengetahui kondisi yang diantara pegawainya, utamanya pimpinan HRD yang membidangi dan berkaitan langsung dengan sumber daya manusia harus bisa merespon dan mengantisipasi permasalahan tersebut. Untuk mengatasi dan menyelesaikan berbagai macam problematika permasalahan tersebut, akhir-akhir ini organisasi atau perusahaan sering menggunakan Outbound Training sebagai salah satu media pembelajaran untuk meningkatkan kompetensi pegawai yang sekaligus sebagai wahana untuk meningkatkan kerjasama diantara pegawai. Kegiatan Outbund Training akan sangat membantu dalam membangun sumber daya manusia yang dapat beradaptasi dan bersosialisasi, baik di dalam lingkungan keluarga, masyarakat serta tempat untuk berkarya secara profesional.

Secara garis besar ada dua tipe penggunaan Outbound Training, pertama adalah untuk pengembangan kemampuan di bidang management organisasi, dan kedua di bidang pengembangan diri (personal development). Kedua tipe penggunaan Outbound Training ini banyak dipakai dalam upaya pelatihan dan 
pembelajaran dalam rangka menumbuhkembangkan serta peningkatan dan pengembangan Sumber Daya Manusia suatu organesari atau institusi.

Perusahaan adalah sebuah institusi sosial tempat orang bekerja dalam suatu sistem sosial (Gibson, et.al, 2001).

Sukses dalam pencapaian tujuan organisasi sangat ditentukan oleh kerjasama diantara sesama pegawai. Untuk mempercepat pengambilan keputusan dalam perusahaan, kini semakin banyak organisasi perusahaan yang merubah strukturnya menjadi struktur berdasarkan tim kerja (team based organisation). Pendekatan organisasi berdasarkan tim kerja menuntut adanya pemberdayaan dan kekompakan kerja (Ray Brontein, 1995).

Untuk merubah kebiasaan kerja dari pekerjaan yang individual menjadi kerja Tim, diperlukan adanya paradigma baru di dalam menangani perusahaan. Pendekatan lintas fungsi ini sangat diperlukan karena terjadi perubahan yang mendasar dalam pelaksanaan kegiatan pekerjaan berorientasi tugas (task-based) menjadi pekerjaan yang berorientasi proses (process based). Pergeseran orientasi meningkatkan efisiensi dalam produktivitas di dalam kegiatan organisasi. Untuk menangani sebuah proses itu mulai dari permulaan proses sampai ke akhir proses. Suatu tim yang kompak harus memiliki visi dan misi bersama yang di kembangkan secara bersama.

Visi ini akan menjadi pengikat kepentingan bersama dari seluruh anggota tim. Selain itu juga, setiap anggota tim juga harus memiliki sikap saling tergantung (interdependence). Oleh karena itu dalam rangka meningkatkan efektifitas tim agar berkinerja baik (high performing team), maka perlu diusahakan agar diantara sesama anggota tersebut dapat terjadi komunikasi yang lancar, baik komunikasi yang bersifat formal maupun komunikasi yang bersifat nonformal, perlu adanya pengembangan : kerja sama; kepemimpinan; budaya organisasi; pengelolaan perubahan; perencanaan strategik; pengembangan diri; motivasi.

Penelitian ini mengembangkan penelitian sebelumnya yakni antaralain dari penelitian Edwardin (2006); Umar (2011); Permatasari (2013); Syafrina, dkk (2013); Muhtadin (2015).

Peranan Outbound menurut Sukrisno (2001), upaya yang sangat strategis dalam rangka meningkatkan kinerja organisasi. Metode outbond sangat populer, karena sangat efektif dalam membangun pemahaman terhadap suatu konsep dan membagun perilaku. Merupakan metode pembelajaran yang dirancang untuk pengembangan diri dan kelompok melalui pembentukan keterbukaan, toleransi, kebersamaan, kepekaan terhadap rasa kebutuhan dan harapan kelompok/orang lain yang memanfaatkan alam sebagai media atau sarana belajar (Departemen Dalam Negeri dan Otonomi Daerah, 2001).

Menurut Ancok (2002), pendidikan melalui kegiatan alam terbuka ini mulai dilakukan pada tahun 1821 saat didirikan Round Hill School. Secara sistematik pendidikan melalui kegiatan outbound dimulai pada tahun 1941 di Inggris. Lembaga pendidikan outbound pertama ini dibangun oleh seorang pendidik berkebangsaan Jermman bernama Kurt Hahn yang bekerjasama dengan seorang pedagang Inggris bernama Lawrence Holt. Kedua orng ini membangun pendidikan berdasarkan petualangan (adventured based education). Pendidikan bertujuan untuk menumbuhkan kesadaran dikalangan muda bahwa tindakan yang 
dilakukan selama pedidikan membawa konsekuensi dan menumbuhkan rasa kebersamaan dan kasih sayang pada orang lain.

Sukses dari lembaga pedidikan tersebut membuat banyak lembaga pendidikan sejenis dibangun diberbagai negara antara lain di Inggris, Eropa, Afrika, Asia dan Australia. Begitu pula di Indonesia, lembaga-lembaga pendidikan manajemen telah banyak menggunakan metode outbound dalam mengajarkan konsep manajemen.

Metode outbound juga telah digunakan untuk kepentingan terapi kejiwaan, meningkatkan konsep diri anak nakal, pecandu narkoba dan kesulitan didalam hubungan social dan penggunaan metode outbound saat ini juga sudah merambah ke dalam pendidikan dan pelatihan aparatur (Lumary, 2003).

Filosofi yang digunakan dalam pelatihan outbound menurut Departemen Dalam Negeri dan Otonomi Daerah (2001) adalah : belajar dari alam, melepaskan rutinitas, eksperimen pengembangan masalah, belajar secara kolektif. Filosofi ini dikembangkan karena prinsip-prinsip belajar dengan praktek akan memberikan hasil yang paling optimal.

Dalam dinamika kelompok peserta belajar tentang proses interaksi, seperti komunikasi, kerjasama, pemecahan masalah, pengambilan keputusan, dan kepemimpinan sebagai suatu proses individu dalam kelompok. Kegiatan refleksi dilakukan pada setiap akhir permainan dimaksudkan agar peserta dapat segera menarik kesimpulan dan manfaat dari proses belajar dalam rangka pemahaman makna permainan untuk menunjang pembentukan pemimpin efektif. Melalui kegiatan refleksi peserta dapat memetik makna dari proses pembelajaran mengarah pada pelaksanaan fungsi manajemen dan manfaat permainan bagi pengembangan kerjasama team dan pengembangan diri untuk menghadapi tantangan berikutnya.

Metode yang dipergunakan dalam pelatihan outbound menurut Departemen Dalam Negeri (2001) adalah metode belajar dari pengalaman (Experiential Learning Cycle). Konsep outbound dikondisikan dalam suatu tantangan yang menarik dengan kegiatan alam terbuka sebagai media belajar. Tantangan fisik dan mental didesain secara khusus untuk memberikan pengaklaman belajar tanpa melampaui kapaasitas fisik seseorang.

Keunggulan outbound menurut Ancok (2002) terletak pada metode belajar yang dipergunakan. Dalam pelatihan outbound metode belajar yang dipergunakan adalah metode belajar dari pengalaman (Eksperiential Learning Cycle). Konsep outbound dikondisikan dalam suatu tantangan yang menarik dengan kegiatan alam terbuka sebagai media belajar. Tantangan fisik dan mental didesain secara khusus untuk memberikan pengalaman belajar tanpa melampaui kapasitas fisik seseorang.

Secara umum, pelatihan outbound bertujuan untuk: meningkatkan kemampuan kerjasama, rasa percaya diri, kepekaan terhadap tanggung jawab dan kebutuhan orang lain; menanamkan rasa cinta, solidaritas dan loyalitas terhadap kelompok; meningkatkan kepekaan terhadap kelestarian lingkungan hidup menumbuhkan dan meningkatkan motivasi dan keyakinan diri anggauta akan kemampuan diri untuk siap berperan mencapai visi dan tujuan kelompok secara kreatif; memberikan suasana penyegaran dan memecahkan kekakuan birokrasi. 
Menurut Ancok (2002) keunggulan suatu organisasi sangat ditentukan oleh keunggulan manusia yang menjalankan organisasi tersebut. Berapa besarnya kemampuan organesasi dalam menyediakan sarana prasarana, seberapa canggihnya teknologi yang dipakai oleh organisasi dan betapa bagusnya perencanaan strategic yang disiapkan tidak akan berarti apa-apa ababila tidak didukung oleh manusia yang berkualitas yang menjalankan organisasi tersebut. Oleh karena itu pengembangan Sumber Daya Manusia memegang peranan strategis dalam rangka pencapaian tujuan organisasi untuk mencapai sasaran unggul yang mampu berorientasi "kita" bukan berorientasi "saya".

Manusia yang unggul yang demikiian itu oleh kovey (1993) disebut sebagai manusia yang efektif. Menurut Gordon (1994) seorang mausia disebut sebagai pimpinan efektif bila anggautaanggauta kelompoknya dapat merasakan bahwa kebutuhan mereka terpenuhi sementara kebutuhanya sendiri tak terabaikan (pertukaran social yang adil). Melalui pelaksanaan outbound dalam berbagai pendidikan dan pelatihan diharapkan dapat menunjang pembentukan pemimpin yang efektif dilingkungan aparatur.

Metode outbound dirancang sebagai pendekatan pelatihan melaluai sebuah simulasi kehidupan komplek menjadi sederhana dengan menggunakan alam sebagai sarana dan media belajar ; outbound membangun gaya belajar reflektif sehingga orang dewasa yang penuh dengan pengalaman-pengalaman dalam hidupnya akan belajar melalui pengalaman nyata, partisipatif, kesediaan berbagi dengan sesama temanya dengan menggunakan metode belajar melalui pengalaman (Experiential Learning Cycle) dan dalam suasana "rekreatif dan demokratis" penuh kegembiraan karena dilakukan dengan berbagai permainan/ games. Peserta terlibat langsung dalam permainan, merasakanya dan akan mengambil pelajaran serta mencari cara untuk perbaikan.

Menurut Direktorat Jenderal Peternakan dan Departemen for International Development (1999) efektifitas belajar dipengaruhi oleh media pembelajaran. Apabila melalui pendengaran saja orang akan mengingat $20 \%$; efektifitas akan meningkat menjadi $40 \%$ apabila menggunakan cara mendengar dan melihat; sedang apabila mengalami sendiri/mengerjakan orang akan mengingat sampai $80 \%$.

Menurut Cremer dan Siregar (1993) seperti terlihat pada gambar 1. Dari Piramida belajar tesebut ternyata bahwa penggunaan media belajar berhubungan dengan efektifitas hasil pembelajaran. Dalam pelaksanaannya, metode outbound telah menggabubungkan berbagai media belajaar, mulai dari mendengarkan, melihat berbicara sampai mengejaakan latihan/game/praktek; ini berarti pelaksanaan outbound sangat mendukung pencapaian tujuan pembelajarran. Hal ini didukung juga oleh Roger C. Schank dalam Dryden, Gordon dan Dr. Jeannette (1999) yang mengatakan bahwa mempraktekan merupakan hal terbaik.

Aktivitas pelatihan yang berupa permainan berkecenderungan untuk disukai oleh banyak orang. Penyelenggaraan outbound dapat merangsang emosi dan kegembiraan pada diri peserta pelatihan. Hal ini didukung pendapat Drygen, Gordon dan Dr. Jeannette Vos (1999) bahwa bagi kebanyakan orang, belajar akan sangat 
efektif jika dilakukan dalam suasana menyenangkan

Untuk merubah kebiasaan kerja dari pekerjaan yang sangat individual menjadi kerja tim diperlukan adanya paradigma baru didalam menangani pekerjaan. Pola kerja lama yang terkotak-kotak dalam unit kerja kecil-kecil yang berdiri sendirisendiri, biro kratis perlu dibongkar dengan pendekatan lintas fungsi. Pendekatan fungsi ini akan meningkatkan efisiensi dan produktifitas di dalam kegiatan organisasi. Suatu team yang kompak harus mempunyai visi bersama yang dikembangkan secara bersama. Visi ini akan menjadi pengikat kepentingan bersama dari seluruh anggota tim. Sukses sebuah organisasi sangat ditentukan oleh kemampuan pemimpinnya dalam menggerakkan seluruh anggauta untuk mencapai tujuan organisasi.

Seorang pemimpin yang handal harus menjadi pemimpin yang sinergistik, yaitu pemimpin yang mampu memadukan kompetensi individual dari masing-masing anggauta menjadi suatu tim kerja yang bekerja secara terpadu yang mengandalkan team secara sinergistik.

Organisasi pemerintah beserta aparaturnya perlu mengantisipsi perubahan yang terjadi sesuai dengan tuntutan zaman. Apabila organisasi pemerintah tidak sensitive akan adanya perubahan maka organisasi tersebut tidak akan memperoleh kemajuan, bahkan sebaliknya akan mengalami kemunduran. Serta menghadapi banyak competitor unggul.

Di awal abad 21 perekonomian Dunia yang menunjukkan perkembangan yang mengarah pada tercapainya perdagangan bebas. Perkembangan baru ini semakin didorong oleh pertumbuhan teknologi informasi yang berkembang dengn pesat sehingga memungkinkan terjadinya paperless transction, penyebaran informasi dalam waktu yang teramat singkat, dan kegitan-kegiatan global lainnya yang mengubah dunia menjadi kawasan tanpa batas. Kondisi demikian tersebut di atas berpengaruh pada perubahan pengembangan organisasi profesionalisme dll. Untuk meningkatkan potensi Sumber Daya Manusia sehingga mampu menghadapi tantangan masa depan.

Sikap manusia atau untuk singkatnya disebut sikap didefinisikan oleh Allen dkk (1980), “ Suatu pola perilaku, tendensi atau kesiapan antisipatif, predisposisi untuk menyesuaikan diri dalam situasi social, atau secara sedarhana, sikap adalah respons terhadap stimulasi social yang telah terkondisikan ".

Sedangkan menurut Scord dan Backman (1964), “ Sebagai keteraturan tertentu dalam hal perasaan (afeksi), pemikiran(kognisi), dan predisposisi tindakan (konasi) seseorang terhadap suatu aspek dilingkkungan sekitarnya.

Menurut Breckler dan Wiggins (1989), "Bahawa sikap yang diperoleh lewat pengalaman akan menimbulkan pengaruh langsung terhadap perilaku berikutnya “. Pengaruh langsung lebih berupa predisposisi perilaku yang akan direalisasikan hanya apabila kondisi dan situasi memungkinkan. Kondisi apa, waktu apa, dan situasi bagaimana saat individu tersebut harus mengekspresikan sikapnya merupakan sebagian dari determinandeterminan yang sangat berpengaruh terhadap konsistensi antara sikap dengan pernyatanya dan antara pernyataan sikap dengan perilaku.

Hapsari (2013), organisasi akan menempatkan visi dan misinya dalam bentuk yang tebaik sehingga organisasi/perusahaan akan mencapai 
perkembangan dan kemajuan yang pesat. Perkembangan dan kemajuan organisasi/perusahaan yang optimal haruslah sejalan dengan dinamika perubahan baik dari sisi internal maupun dari sisi eksternal organisasi. Hal tersebut sesuai dengan pernyataan Rudianto (2010) organisasi haruslah memiliki sumber daya manusia yang mampu menampilkan kinerja yang baik.

Permasalahan mengenai sumber daya manusia seringkali dinilai permasalahan klasik yang remeh temeh, padahal jika tidak ditangani secara serius, organisasi akan rentan mengalami kemunduran, ketidaksiapan menghadapi perubahan ataupun tergilas oleh competitor (Ismara, 2006). Salah satu usaha untuk mengatasi permasalahan mengenai sumber daya manusia sebagai penggerak organisasi adalah dengan mempertajam kompetensi yang mereka miliki.

Thateher (dalam susilo,2000) mengatakan bahwa kesuksesan hanya dapat dicapai dengan kerja keras. Kerja keras tidak selalu membawa menuju puncak prestasi, tetapi pasti membawa kita sangat dekat dengan kesuksesan.

Dalam dunia kerja, menurut Edison (dalam Stolz, 2001) diperlukan kesuksesan untuk menetapkan sasaran kerja berupa produktifitas dan pencapaian. Untuk mencapai keduanya diperlukan pemikiran, perencanaan, kecerdasan, kejelasan tujuan, dan keringat. Namun yang kerap terjadi adalah individu sebagai pemilik kompetensi mengalami kegagalan dikarenakan keputusan mereka untuk menyerah (Dryden, 2001).

Menurut Stolz (2001), Dikatakan juga bahwa AQ berakar pada bagaimana kita merasakan dan menghubungkan dengan tantangan-tantangan. Orang yang memiliiki AQ lebih tinggi tidak menyalahkan pihak lain atas kemunduran yang terjadi dan mereka bertanggung jawab untuk menyelesaiakn masalah. AQ akan merangsang diri untuk memikirkan kembali rumusan keberhasilan diri yang sekarang ini.

Dalam Adversity Quotient yang menjadi sorotan adalah seberapa jauh kemampuan seseorang untuk dapat bertahan ketika mendapat kesulitan dan dapat mengatasi kesulitan-kesulitanya. Banyak individu yang menyerah sebelum bertanding ketika berhadapan dengan tantangan hidup.. Hal ini menunjukkan betapa rendahnya daya tahan terhadap ancaman. Daya tahan terhadap ancaman tersebut seringkali kita kenal dengan tabah. Toto Tasmara (2001) mengatakaan bahwa mereka yang memiliki sifat tabah adalah mereka yang mampu menghadapi tekanan.

Peningkatan AQ menjadi penting karena dapat memperbaiki ketahanan seseorang untuk menghadapi berbagai keadaan, baik keadaan yang menyenangkan maupun yang sulit di pekerjaan (Ismara, 2006).

Ditilik dari sejarahnya, outbound sebenarnya adalah kegiatan pelatihan di alam terbuka yang memerlukan ketahanan dan skaligus tantangan fisik yang besar. Bentuk kegiatan outbound, yakni berupa simulasi kehidupan melalui permainanpermainan (games) yang kreatif, rekreatif dan educative, baik secara individu maupun kelompok, dengan tujuan untuk pengembangan diri (personal development) maupun kelompok (team development). Melalui Outbound diharapkan lahir pribadi yang tangguh (Adversity Quotient) (Asti, 2009).

Danuminarto (2007: 11) mengatakan: “ Experiential learning adalah suatu bentuk dukunggan yang kongkret terhadap hubungan teori dengan praktek di dalam 
dunia nyata, yang mana peserta yang terlibat dalam proses Pembelajaran akan mendapatkan hasil yang terbaik ".

Djoko Kusumowidagdo (2002) inti dari batasan tersebut dimana outward bound berperan penting bagi orang yang tidak pernah menyerah, yang ingin mencoba dan mencoba lagi, dan yang mencoba terus untuk meraih batas waktu yang tidak diketahui. Dengan demiikian dapat dipahami bahwa kegiatan outbound mempunyai tujuan untuk mebangun manusia yang memiliki ketahanan mental yang kokoh, pantang menyerah, selalu ingin mencoba, menghargai orang lain dan sebagainya. Dalam kegiatan outbound, mereka akan mencoba untuk menggali potensi yang dimiliki yang selama ini mungkin terpendam.

Hal inilah yang menjadi dasar bagaimmana pentingnya kemampuan berfikir kritis , karena dalam berfikir kritis terdapat beberapa keterampilan, salah satunya adalah keterapilan dalam mengevaluasi. Berkaitan dengan ini Missimer (1990) dikutip Filsaime (2007) alih bahasa Sunarni (2008: 69) menjelaskkan bahwa: "Kecakapan untuk mengevaluasi sebuah argument adalah unsur dasar dan paling penting dalam berpikir kritis". Selanjutnya Filsaime (2007) alih bahasa Sunarni (2008: 84) menjelaskan pula bahwa teori-teori berpikir kritis menunjukkan pada; "keterlibatan kemampuan-kemampuan analisis, interprestasi, inferens, eksplanasi, dan evaluasi."

Proses ini sangat kentara dengan corak permainan outbound yang melibatkan aksi menantang, berpikir, bekerja keras, bekerjasama serta nilai disiplin dan tanggungjawab. Siswa yang berpikir kritis adalah siswa yang mampu mengidentifikasi, mengevaluuasi, dan mengkonstruksi argument serta mampu memecahkan masalah dengan tepat Spliter 1991) dalam Redhana (2003:12-13)

Berpikir kritis telah diterima sebagai salah satu pendekatan tertua dan sangat terkenal untuk kecakapan-kecakapan kecerdasan. Pentingnya berpikir kritis dalam aktifitas-aktivitas harian manusia dapat menyatakan bahwa hanya priibadipribadi yang cakaap yang memiliki kemampuan untuk terus berkembang. Mengenai pengetian berpikir kritis, Robbert Ennis (1989) dalam Fisher (2007) alih bahasa Hadinata (2009:4) mendefinisikan bahwa: "Berpikir kritis adalah pemikiran yang masuk akal dan reflektif yang berfokus untuk memutuskan apa yang mesti dipercaya atau dilakukan”. Dalam hal ini jelas bahwa kemampuan untuk memahami dan merefleksikan apa yang dirasa, dilihat, dialami, dan didengar merupakan definisi dari berpikir kritis.

Pendapat senada disampikan Screven dan Paul (1995) dan Anggelo (1995) dalam Filsaime (2007) alih bahasa Sunarni (2008:56), berpikir kritis sebagai proses disiplin cerdas dari konseptualisasi, penerapan analisis, sintesis dan evaluasi aktif dan berketerampilan yang dikumpulkan dari, atau dihasilkan oleh observasi, pengalaman, refleksi, penalaran, atau komunikasi sebagai sebuah penuntun menuju kepercayaan dan aksi.

Zaman dan helmi (2010: 4) menegaskn bahwa: "Permainan yang disajikan dalam outbound memang telah disusun sedemikian rupa, sehingga bukan psikomotorik (fisik) peserta yang "tersentuh" tapi juga afeksi (emosi) dan kognisi (kemampuan berfpikir).

Komunikasi secara terminologis merujuk pada adanya proses penyampaian suatu pernyataan oleh seseorang kepada orang lain. Jadi dalam pengertian ini yang 
terlibat dalam komunikasi adalah manusia. Karena itu merujuk pada pengertian Ruben dan Steward(1998:16).

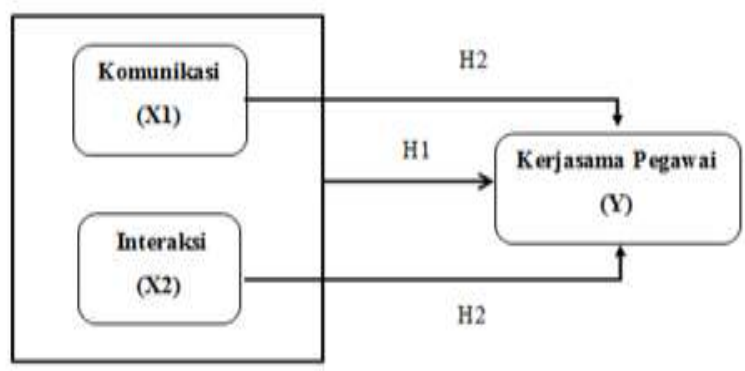

Gambar Kerangka Teori

\section{HIPOTESIS :}

H1: Komunikasi dan Interaksi dalam simulasi game kegiatan Outbound Training berpengaruh secara simultan terhadap kerjasama pegawai

H2: Komunikasi dan Interaksi dalam simulasi game kegiatan Outbound Training berpengaruh secara parsial terhadap kerjasama pegawai

\section{METODE PENELITIAN}

Jenis penelitian ini adalah penelitian eksploratif, yaitu dilakukan dengan cara mengumpulkan data melalui angket, wawancara maupun dokumentasi. Populasinya adalah pegawai, praktisi dan guru, dari beberapa perusahaan dan lembaga pendidikan yang ada di wilayah Malang, Pasuruan, Mojokerto, Sidoarjo dan Surabaya yang mengadakan kegiatan Outbound Training dengan Lembaga Pelatihan dan Pengembangan - Sumber Daya Manusia (LPP-SDM) NABHAN STAR. Dalam waktu 7 bulan penelitian didapatkan 10 perusahaan dan lembaga pendidikan yang mengadakan Outbound Training, yang setiap kali kegiatan Outbound Training diikuti oleh peserta dengan jumlah antara 40 - 150 orang. Dari 10 perusahaan dan lembaga pendidikan yang mengadakan kegiatan Outbound Training terdapat 6 perusahaan dan lembaga pendidikan yang mengadakan kegiatan Outbound Training dengan tema Komunikasi dan Interaksi dengan total jumlah peserta 376 orang.

Ssampel berjumlah 79 dengan dengan menggunakan rumus Slovin yaitu sebagai berikit :

$$
n=\underset{c}{1+N e^{2}}=\frac{376=79}{1+376(0,10)^{2}}
$$

Keterangan :

$\mathrm{n} \quad:$ Jumlah sampel

$N$ : Jumlah populasi

e : tingkat kesalahan $10 \%$

Adapun pengambilan sampel dengan menggunakan teknik Proportional Stratified Random Sampling yaitu dengan cara membagi populasi menjadi beberaqpa kelompok dan selanjutnya secara random memilih sampel dari masing-masing kelompok.

Analisis data kuantitatif dengan uji asumsi klasik regresi linear OLS adalah sebuah model regresi linear dengan metode perhitungan kuadrat terkecil atau yang di dalam bahasa inggris disebut dengan istilah ordinary least square.

Uji multikolineritas bertujuan untuk menguji apakah dalam model regresi ditemukan adanya korelasi antar variabel bebas, pada model regresi yang baik seharusnya tidak terjadi antara variabel bebas dan variabel independen.

Uji Heteroskedasitas bertujuan menguji apakah dalam model regresi terjadi ketidaksamaan varian atau residual satu pengamatan ke pengamatan lainnya, jika variabel residual satu pengamatan ke pengamatan lainnya tetap maka disebut 
homokedastisitas dan jika berbeda disebut heteroskedasitas.

Pengujian dengan $\mathrm{BG}$ didasarkan pada hipotesa nol: $\rho_{1}=\rho_{2}=\ldots=\rho_{\mathrm{p}}=0$ yang menunjukkan bahwa tidak terjadi autokorelasi pada setiap orde.

Teknik analisis yang digunakan untuk menguji hipotesis adalah dengan analisis regresi liner berganda dengan metode bantuan SPSS digunakan untuk meneliti pengaruh dari beberapa variabel independen terhadap variabel dependen. Menurut Dr.Suliyanto Persamaan regresi linier berganda. Uji hipotesis menggunakan uji F (Simultan); Uji t (Parsial) dan koefisien determinasi $\left(\mathrm{R}^{2}\right)$.

\section{HASIL DAN PEMBAHASAN}

Berdasarkan permasalahan yang telah dikemukakan, untuk memberikan jawaban atas hipotesis penelitian yang berjudul Analisis Pengaruh Komunikasi dan Interaksi pada Kegiatan Outbound Training Terhadap Kerjasama Pegawai, maka akan dilakukan pengujian kualitas Instrumen dan data yang meliputi uji asumsi klasik, koefisien determinasi dan pengujian simultan kemudian dilakukan uji hipotesis yang meliputi analisis regresi, uji $\mathrm{t}$ dan analisis jalur, berikut penjabarannya:

\section{Uji Kualitas Instrumen dan Data, yang meliputi:}

\section{Uji Asumsi Klasik}

Uji asumsi klasik dilakukan dengan menggunakan analisis regresi berganda terhadap variabel independen dan variabel dependen, serta variabel intervening. Adapun dalam penelitian ini variabel independen yang digunakan adalah outbound training, dan variabel intervening adalah komunikasi dan interaksi. Sedangkan variabel dependen yang digunakan adalah kerjasama pegawai. Uji asumsi klasik yang telah dilakukan dan hasilnya adalah sebagai berikut:

\section{Uji Multikolinieritas}

Pengujian dalam uji multikolinearitas dengan melihat nilai Pairwise Correlations harus berada dibawah 0.8, hal ini akan dijelaskan pada tabel berikut:

Tabel : Output Uji Multikolinieritas

\begin{tabular}{c|c|c|}
\hline & $\mathbf{X 1}$ & $\mathbf{X} 2$ \\
\hline $\mathbf{X 1}$ & 1.000000 & 0.691329 \\
\hline $\mathbf{X} 2$ & 0.691329 & 1.000000 \\
\hline & &
\end{tabular}

Berdasarkan tabel di atas dapat diketahui bahwa hasil uji multikolonieritas menunjukkan nilai Pairwise Correlations kurang dari 0.8 untuk setiap variabel. Hasil tersebut menunjukan bahwa pada variabel yang diteliti tidak terdapat multikolinearitas.

\section{Uji Autokorelasi}

Untuk menguji apakah terdapat autokorelasi pada penelitian ini maka digunakan uji Breusch-Godfrey. Hipotesis yang digunakan dalam pengujian ini adalah, sebagai berikut:

$H 0$ : tidak ada autokorelasi

$H 1$ : terdapat autokorelasi

Keputusan ada tidaknya autokorelasi dilihat berdasarkan nilai yang dihasilkan pada saat dilakukan pengolahan menggunakan Eviews pada tabel model summary.

HO diterima atau data dikatakan tidak terdapat autokorelasi apabila memenuhi syarat tertentu, yaitu nilai probability obs*R-Squared $>0.05$. Hasil pengujian pada penelitian ini akan ditunjukan pada tabel dibawah ini: 
Tabel : Output Uji Autokorelasi

Breusch-Godfrey Serial Correlation LM Test:

\begin{tabular}{|c|c|c|c|c|}
\hline $\begin{array}{l}\text { F-statistic } \\
\text { Obst-squared }\end{array}$ & $\begin{array}{l}0.005236 \\
0.011179 \\
\end{array}$ & $\begin{array}{l}\text { Probability } \\
\text { Probability }\end{array}$ & & $\begin{array}{l}0.994778 \\
0.994426 \\
\end{array}$ \\
\hline \multicolumn{5}{|c|}{$\begin{array}{l}\text { Test Equation: } \\
\text { Dependert Variable: RESID } \\
\text { Method: Least Squares } \\
\text { Date: 0903/18 Time: } 12: 31 \\
\text { Presample missing value lagged residuals set to zeno. }\end{array}$} \\
\hline Variable & Coeficient & Std. Error & t-Statistic & Prob. \\
\hline $\begin{array}{c}c \\
\times 1 \\
x 2 \\
\text { RESID(-1) } \\
\text { RESID }(-2)\end{array}$ & $\begin{array}{r}0.031086 \\
-0.001928 \\
-0.000388 \\
-0.004726 \\
-0.011204\end{array}$ & $\begin{array}{l}2.606982 \\
0.260027 \\
0.236190 \\
0.117960 \\
0.118159\end{array}$ & $\begin{array}{r}0.011915 \\
-0.007416 \\
-0.001641 \\
-0.040062 \\
-0.094823\end{array}$ & $\begin{array}{l}0.9905 \\
0.9941 \\
0.9987 \\
0.9682 \\
0.9247\end{array}$ \\
\hline $\begin{array}{l}\text { R-squared } \\
\text { Adjusted R-squared } \\
\text { S.E. of regression } \\
\text { Sum squared resid } \\
\text { Log likelihood } \\
\text { Durbin-Watson stat }\end{array}$ & $\begin{array}{r}0.000142 \\
-0.053905 \\
2.492665 \\
459.7900 \\
-181.6684 \\
1.933151\end{array}$ & \multicolumn{2}{|c|}{$\begin{array}{l}\text { Mean dependent var } \\
\text { S.D. dependent var } \\
\text { Akcaike info criterion } \\
\text { Schwarz criterion } \\
\text { F-statistic } \\
\text { Prob(F-statistic) }\end{array}$} & $\begin{array}{r}-7.60 E-16 \\
2.428081 \\
4.725781 \\
4.875746 \\
0.000618 \\
0.999986\end{array}$ \\
\hline
\end{tabular}

Berdasarkan tabel diatas dapat diketahui bahwa hasil uji autokorelasi pada nilai probability obs*R-Squared adalah 0.994426>0.05, maka syarat terpenuhi atau $H 0$ diterima, dan dapat disimpulkan bahwa data yang digunakan dalam penelitian ini bebas dari autokorelasi.

\section{Uji Heterokedastisitas}

Pengujian untuk penelitian ini akan digunakan Uji White secara statistik. untuk lolos dari asumsi klasik ini diharuskan setiap variabel memilki nilai probability obs*R-Squared >0,05. Hasil pengujian akan ditunjukan pada tabel berikut ini:
Tabel : Output Uji Heterokedastisitas

White Heteroskedasticity Test:

\begin{tabular}{llll}
\hline \hline F-statistic & 1.030547 & Probability & 0.406203 \\
Obs*R-squared & 5.208596 & Probability & 0.390957 \\
\hline \hline
\end{tabular}

Test Equation:

Dependent Variable: RESID²

Method: Least Squares

Date: 09/03/18 Time: 12:32

Sample: 179

Included observations: 79

\begin{tabular}{crlll}
\hline \hline Variable & Coefficient & Std. Error & t-Statistic & Prob. \\
\hline \hline C & 29.43753 & 79.23977 & 0.371499 & 0.7113 \\
$X 1$ & -17.11068 & 15.00411 & -1.140399 & 0.2578 \\
$X 1 \times 2$ & 0.759657 & 0.681574 & 1.114563 & 0.2687 \\
$\times 1 * \times 2$ & -0.290642 & 0.662971 & -0.438393 & 0.6624 \\
$X 2$ & 12.82386 & 11.46817 & 1.118214 & 0.2671 \\
$X 2^{n 2}$ & -0.279769 & 0.501752 & -0.557584 & 0.5788 \\
\hline \hline R-squared & 0.065932 & Mean dependent var & 5.820950 \\
Adjusted R-squared & 0.001954 & S.D. dependent var & 9.040963 \\
S.E. of regression & 9.032124 & Akaike info criterion & 7.312363 \\
Sum squared resid & 5955.287 & Schwarz criterion & 7.492321 \\
Log likelihood & -282.8383 & F-statistic & 1.030547 \\
Durbin-Watson stat & 1.975777 & Prob(F-statistic) & 0.406203 \\
\hline \hline
\end{tabular}

Berdasarkan tabel diatas, dapat diketahui bahwa tidak ada satupun variabel yang memiliki nilai sig. $0.390957>0,05$ yang menyatakan bahwa data telah lolos heterokedastisitas.

\section{Uji Normalitas}

Pada penelitian ini menggunakan uji statistik Jarque-bera untuk melihat apakah residual berdistribusi normal atau tidak. Model regresi yang baik adalah distribusi data normal atau mendekati normal. Maka terdapat hipotesis yang harus dibuat untuk pengujian tersebut, hipotesisnya adalah:

$H 0$ : data residual berdistribusi normal

: data residual tidak berdistribusi normal Berdasarkan pengolahan pada Eviews terkait uji normalitas, hasil yang diperoleh dari uji Jarque-bera akan ditunjukan pada Tabel sebagai berikut: 
Tabel : Output Uji Normalitas

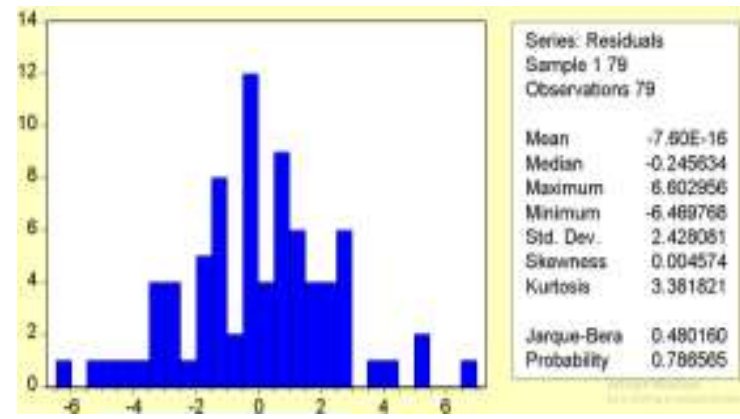

Dari table di atas, diketahui nilai probability Jarque-bera sebesar 0.786565 signifikan lebih dari 0,05 . Hal ini menyatakan bahwa $H 0$ diterima, atau berarti data yang diteliti berdistribusi normal pada penelitian.

\section{Koefisien Determinasi}

Koefisien determinasi ( $\mathrm{R}$ Square) digunakan seberapa besar variabel independen dapat menjelaskan variabel dependen. Nilai determinasi ditentukan dengan niai $\mathrm{R}$ square untuk regresi sederhana dan Adjusted R square untuk regresi berganda. Berdasarkan pengolahan data menggunakan SPSS 22, diperoleh nilai koefisien determinasi ketiga model penelitian pada Tabel berikut:

Tabel : Output Koefesien Determinasi

\begin{tabular}{|l|c|r|r|r|}
\hline Model & R & R Square & $\begin{array}{c}\text { Adjusted R } \\
\text { Square }\end{array}$ & $\begin{array}{c}\text { Std. Error of } \\
\text { the Estimate }\end{array}$ \\
\hline 1 & $.549^{\circ}$ & .301 & .283 & 2.45982 \\
\hline
\end{tabular}

Hasil perhitungan koefisien korelasi (R), menunjukkan bahwa sebesar 0,549 atau $54.9 \%$ mempunyai tingkat hubungan rendah dari variabel independent yaitu komunikasi (X1) dan interaksi (X2) terhadap variabel dependent yaitu kerjasama pegawai (Y). Sedangkan hasil koefisien determinasi (R Square), diketahui bahwa nilai $\mathrm{R}$ Square dari variabel independent yaitu komunikasi (X1) dan interaksi (X2) terhadap variabel dependent yaitu kerjasama pegawai (Y) yang diperoleh sebesar 0.301 atau $30.1 \%$. Hal ini dapat diartikan bahwa sekitar $30.1 \%$ variabel kerjasama pegawai dapat dijelaskan oleh variabel komunikasi dan interaksi sedangkan sisanya yaitu $69.9 \%$ dipengaruhi oleh variabel-variabel lainnya yang tidak diteliti dalam penelitian ini.

\section{Pengujian Simultan}

Uji statistik $F$ bertujuan untuk menunjukan apakah semua variabel independen pada penelitian dapat memengaruhi variabel dependen secara simultan atau bersama-sama dalam model penelitian.

Berikut adalah hasil uji simultan untuk model kedua dalam penelitian ini:

\begin{tabular}{|c|c|c|c|c|c|c|}
\hline Model & & $\begin{array}{c}\text { Sum of } \\
\text { Squares }\end{array}$ & Df & Mean Square & $F$ & Sig. \\
\hline 1 & $\begin{array}{l}\text { Regression } \\
\text { Residual } \\
\text { Total }\end{array}$ & \begin{tabular}{l|}
198.221 \\
459.855 \\
658.076
\end{tabular} & \begin{tabular}{r|}
2 \\
76 \\
78
\end{tabular} & $\begin{array}{r}99.110 \\
6.051\end{array}$ & 16.380 & $.000^{\circ}$ \\
\hline
\end{tabular}

Diketahui berdasarkan tabel nilai F-hitung sebesar 16.380 dengan nilai sig. 0,000 < 0,05 . Dengan ini dapat disimpulkan bahwa Komunikasi dan interaksi dalam simulasi game kegiatan outbound Training berpengaruh secara simultan terhadap kerjasama pegawai

\section{HASIL DAN PEMBAHASAN}

\section{Hasil}

Pengujian pada penelitian ini yaitu menggunakan regresi berganda dimana pengujian terhadap variabel dependen dapat menggunakan dua atau lebih variabel independen dan diharuskan memenuhi kriteria BLUE (Best Linear Unbiased Estimator). Berdasarkan hasil uji asumsi klasik yang telah dilakukan, diketahui bahwa data pada penelitian memenuhi kriteria, atau dengan kata lain tidak adanya multikolinearitas, bebas autokorelasi, tidak terdapat heterokedastisitas, dan berdistribusi normal. Maka dari itu data telah memenuhi syarat untuk dilakukan 
regresi linear berganda. Adapun Variabel yang diuji pada analisis regresi ini yaitu Komunikasi (X1) dan Interaksi (X2) terhadap Kerjasama Pegawai (Y). Berikut adalah hasil output analisis regresi berganda yang telah diolah menggunakan SPSS:

Tabel : Output Analivis Regresi Limier Berganda

\begin{tabular}{|c|c|c|c|c|c|c|}
\hline \multirow[b]{2}{*}{ Model } & & \multicolumn{2}{|c|}{ Unstandardized Coefficients } & \multirow{2}{*}{\begin{tabular}{c|}
$\begin{array}{c}\text { Standardized } \\
\text { coefficients }\end{array}$ \\
Beta
\end{tabular}} & \multirow[b]{2}{*}{ t } & \multirow[b]{2}{*}{ Sig. } \\
\hline & & $B$ & Std. Error & & & \\
\hline 1 & Cossant & 8.496 & 2530 & & 3.348 & 005 \\
\hline & $\mathrm{xt}$ & 974 & 254 & 588 & 3831 & 000 \\
\hline & 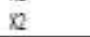 & .039 & 233 & 0.056 & 425 & 572 \\
\hline
\end{tabular}

Hasil analisis regresi linier berganda menggunakan probabilitas dengan tingkat signifikansi sebesar 5\%. Berdasarkan tabel dapat dilihat bahwa nilai koefisien (B) yang bernilai positif yang menunjukan antara variabel independen dan variabel dependen memiliki hubungan positif, sehingga terbentuk persamaan regresi, yaitu:

$$
\mathrm{Y}=8.498+0.974 \mathrm{X} 1+0.099 \mathrm{X} 2+\mathrm{E}
$$

Hasil persamaan menunjukan Komunikasi (X1) memiliki arah koefisien positif. Hal ini menunjukan bahwa meningkatnya Komunikasi juga akan meningkatkan Kerjasama Pegawai. Juga Interaksi (X2) memiliki arah koefisien positif. Hal ini menunjukan bahwa meningkatnya interaksi juga akan meningkatkan Kerjasama Pegawai.

H2: Komunikasi dan interaksi dalam simulasi game kegiatan Outbound Training berpengaruh secara parsial terhadap kerjasama pegawai

\section{Uji t (Pengujian Koefisien Regresi Parsial)}

Uji parsial digunakan untuk menguji pengaruh komunikasi dan interaksi terhadap kerjasama pegawai secara parsial.
Uji parsial dalam penelitian ini dilakukan untuk mengetahui pengaruh masingmasing ketiga variabel komunikasi dan interaksi terhadap kerjasama pegawai. Pengujian koefisien regresi parsial yang dilakukan berdasarkan pada ketiga model penelitian yang telah dijelaskan sebelumnya. Hasil pengujian parsial komunikasi menunjukkan nilai $\mathrm{t}$ hitung sebesar 3.831 dengan nilai signifikansi $0.000<0,05$ yang berarti komunikasi berpengaruh positif signifikan terhadap kerjasama pegawai. Hasil pengujian parsial interaksi menunjukkan nilai $\mathrm{t}$ hitung sebesar 0.425 dengan signfikansi 0,672 > 0,05 yang berarti interaksi tidak berpengaruh positif signifikan terhadap kerjasama pegawai.

\section{Pembahasan}

Komunikasi dan interaksi pada simulasi game kegiatan outbound training berpengaruh secara simultan terhadap kerjasama pegawai. Pengujian hipotesis pertama menguji komunikasi dan interaksi dalam simulasi game kegiatan outbound training mempunyai pengaruh secara simultan terhadap kerjasama pegawai, dimana hasil pengujian secara simultan komunikasi dan interaksi dalam simulasi game kegiatan outbound training menunjukkan nilai F-hitung sebesar 16.380 dengan nilai signifikansi $0.000<0,05$ yang berarti komunikasi dan interaksi dalam simulasi game kegiatan outbound training berpengaruh positif signifikan terhadap kerjasama pegawai. Dengan kata lain, H1 diterima, artinya ada pengaruh secara bersama-sama antara variabel komunikasi dan interaksi terhadap kejasama pegawai. Dalam pelaksanaannya, metode outbound menggabubungkan berbagai media belajar, mulai dari mendengarkan, melihat, berbicara sampai mengerjakan latihan/game/praktek. Hal ini mendukung 
hasil penelitian bahwa kegiatan outbound dan berbicara dalam hal ini komunikasi dan interaksi secara bersama-sama akan berdampak pada kerjasama pegawai.

Komunikasi pada simulasi game kegiatan outbound training mempunyai pengaruh secara parsial terhadap kerjasama pegawai. Pengujian hipotesis kedua menguji komunikasi pada simulasi game kegiatan outbound training mempunyai pengaruh secara parsial terhadap kerjasama pegawai, dimana hasil pengujian secara parsial komunikasi pada simulasi game kegiatan outbound training menunjukkan nilai t hitung sebesar 3.831 dengan nilai signifikansi $0.000<0,05$ yang berarti komunikasi pada simulasi game kegiatan outbound training berpengaruh positif signifikan terhadap kerjasama pegawai. Dengan kata lain, H2 untuk komunikasi diterima, artinya semakin baik dan sering dilakukan komunikasi pada simulasi game kegiatan outbound training, maka akan semakin baik pula kerjasama antar pegawai.

Outbound Manajemen Training merupakan sebuah metode pengembangan diri melalui pengalaman (learning by experience) sebagai salah satu bentuk aktifitas luar ruang (outdoor activities) yang penuh dengan kegembiraan dan tantangan. Efektifitas pelatihan dicapai melalui lima tahapan proses, yaitu aksi, diskusi, refleksi, perencanaan perbaikan dan implementasi.

Penjabaran pada proses diatas, mendukung hasil penelitian bahwa kegiatan outbound yang dilakukan mengharuskan peserta untuk berdiskusi dalam hal ini komunikasi pada simulasi game kegiatan outbound training akan berdampak pada kerjasama pegawai.

Sedangkan Interaksi pada simulasi game kegiatan outbound training tidak memiki pengaruh secara parsial terhadap kerjasama pegawai. Hasil pengujian secara parsial outbound training menunjukkan nilai $\mathrm{t}$ hitung sebesar 0.425 dengan signifikansi $0.672>0,05$ yang berarti Interaksi pada simulasi game kegiatan outbound training tidak berpengaruh positif signifikan terhadap kerjasama pegawai. Dengan kata lain $\mathrm{H} 2$ untuk interaksi ditolak, artinya ada tidaknya Interaksi pada simulasi game kegiatan outbound training yang dilakukan, maka kerjasama antar pegawai tidak akan berubah (tetap).

Penjelasan tentang Interaksi, dalam metode pengumpulan data yang dilakukan dalam penelitian ini disebutkan dengan menggunakan angket, wawancara dan dokumentasi. Untuk melengkapi hasil penelitian setelah dilakukan olah data peneliti juga melakukan wawancara dengan responden. Terkait dengan interaksi sebagian responden menyatakan bahwa interaksi juga komunikasi (ada yang menganggap sama), sehingga dalam menyampaikan jawaban dalam angket cenderung tidak memperhatikan interaksi dan menganggapnya kurang ada interaksi. Setelah dilakukan wawancara, responden memahami bahwa serangkaian proses tahapan kegiatan outbound yaitu: aksi (ada unsur Interaksi dan komunikasi), diskusi (ada unsur interaksi dan komunikasi), refleksi, perencanaan dan implementasi (semuanya mengandung unsur interaksi dan komunikasi). Dan responden menyatakan pada simulasi game outbound training ada interaksi ada komunikasi dan ada interaksi dan komunikasi yang masingmasing dan bersama-sama dapat meningkatkan kerjasama pegawai.

Berikut bentuk-bentuk interaksi seperti yang telah dijelaskan Shaw, Interaksi verbal yang merupakan salah satu bentuk interaksi yang terjadi dalam bentuk percakapan satu sama lain, kemudian Interaksi fisik yakni salah satu bentuk interaksi yang terjadi menggunakan bahasa 
tubuh dan Interaksi emosional sebagai salah satu bentuk interaksi yang terjadi dengan melakukan curahan perasaan interaksi, bentuk-bentuk inilah yang pada penelitian tidak memberi dampak pada kerjasama dalam kegiatan outbound training, yang artinya ada tidaknya interaksi yang dilakukan maka kerjasama pegawai tidak akan berubah.

Filsaime (2007) alih bahasa Sunarni (2008: 84) menjelaskan bahwa teori-teori berpikir kritis menunjukkan pada; "keterlibatan kemampuankemampuan analisis, interprestasi, inferens, eksplanasi, dan evaluasi." Proses ini sangat kentara dengan corak permainan outbound yang melibatkan aksi menantang, berpikir, bekerja keras, bekerjasama serta nilai disiplin dan tanggungjawab. Berdasarkan hal tersebut, maka kerjasama pada kegiatan outbound sebagian besar menuntut untuk berpikir dan lebih mengedepankan kemampuan bekerja keras serta nilai disipilin dan tanggungjawab bukan hanya melalui interaksi saja pada saat kegiatan outbound berlangsung.

\section{PENUTUP}

\section{Simpulan dan Saran}

Berdasarkan hasil pengujian statistik dan pembahasan, maka dapat ditarik beberapa kesimpulan antara laim komunikasi dan interaksi pada simulasi game kegiatan outbound training berpengaruh secara simultan terhadap kerjasama pegawai. Hal ini dibuktikan dengan nilai F-hitung sebesar 16.380 dengan nilai sig. $0,000<0,05$.

Komunikasi pada simulasi game kegiatan outbound training berpengaruh secara parsial terhadap kerjasama pegawai. Hal ini dibuktikan dengan nilai t-hitung sebesar 3.831 dengan nilai sig. $0,000<$ 0,05 . Sedangkan interaksi pada simulasi game kegiatan outbound training tidak berpengaruh secara parsial terhadap kerjasama pegawai. Hal ini dibuktikan dengan nilai t-hitung sebesar 0.425 dengan nilai sig. $0,672>0,05$.

\section{DAFTAR PUSTAKA}

Al-Maqassary, Ardi. 2013. Pengertian Komunikasi Menurut Para Ahli. (online), (https://www.ejurnal.com/2013/10/pengertiankomunikasi-menurut-paraahli.html, diakses pada Juni 2018)

Edwardin, Laras tris ambar suksesi.2006. Analisis pengaruh kompetensi komunikasi, kecerdasan emosional, dan budaya organisasi terhadap kinerja karyawan. (online), (http://eprints.undip.ac.id/15698/, diakses pada Juli 2018)

Muhtadin. 2015. Peran kegiatan outbound sebagai wahana pengembangan social intelligence bagi team outbound lp2kis yogyakarta. (online), (http://digilib.uinsuka.ac.id/19172/, diakes pada Juli 2018)

Mohammad Ali dan Mohammad Asrori, 2010. Psikologi Remaja (Perkembangan Peserta Dididik). Penerbit PT Bumi Aksara: Jakarta

Permatasari, Rindy jihan. 2013. Upaya meningkatkan interaksi sosial melalui experiential learning dengan teknik outbound pada siswa kelas vii a di smp negeri 13 semarang. (online), (http://lib.unnes.ac.id/17330/1/130 1408063.pdf, diakses pada Juli 2018) 


\section{JURNAL NOMOSLECA}

Volume 5 Nomor 2, Oktober 2019

Syafrina, Rizqi H., Fuad nashori., Ratna Rachmahana. 2013. Pengaruh pelatihan outbond terhadap peningkatan tim kerja guru madrasah tsanawiyah “ $j b$ ”. (online),

(https://www.researchgate.net/publ ication/313257552_pengaruh_pelat ihan_outbond_terhadap_peningkat an_tim_kerja_guru_madrasah_tsan awiyah_jb, diakses pada Juli 2018)

Umar, Totong. 2011. Pengaruh outbond training terhadap peningkatan rasa percaya diri kepemimpinan dan kerjasama tim. (online), (http://download.portalgaruda.org/ article.php?article $=57503 \&$ val $=14$ 12, diakses pada Juli 2018)

Winarno, Wing Wahyu, 2015. Analisis Ekonometrika dan Statistika dengan Eviews edisi keempat. Yogyakarta, UPP STIM YKPN 